\title{
Identifikasi Bilangan Gelombang Daun Sirih (Piper sp.) Menggunakan Metode Spektroskopi Fourier Transform Infrared (FTIR) dan Principal Component Analysis (PCA)
}

\section{Identification of Betel Leaf Wave Numbers (Piper sp.) Using Fourier Transform Infrared (FTIR) Spectroscopy Methods and Principal Component Analysis (PCA)}

\author{
Ayu Anisa Damayanti ${ }^{1}$, Ni Luh Putu Trisnawati ${ }^{2 *}$, Hery Suyanto ${ }^{3}$ \\ 1, 2, 3 Program Studi Fisika, Fakultas Matematika dan Ilmu Pengetahuan Alam, Universitas Udayana, \\ Kampus Bukit Jimbaran, Badung, Bali, Indonesia 80361 \\ *Email: ayuanisadamayanti@student.unud.ac.id; *trisnawati@unud.ac.id; hery@unud.ac.id
}

\begin{abstract}
Abstrak - Telah dilakukan penelitian mengenai identifikasi bilangan gelombang daun sirih (Piper sp.) menggunakan metode spektroskopi Fourier Transform Infrared (FTIR) dan Principal Component Analysis (PCA). Jenis daun sirih yang digunakan adalah sirih merah (Piper Crocatum), sirih hijau (Piper Betle L.), dan sirih hitam (Piper Betle V.). Pengujian dilakukan pada serbuk daun sirih dengan perbandingan massa daun sirih dengan $\mathrm{KBr} 4: 1$, masing-masing 0,011528 g dan 0,002882 $\mathrm{g}$. Hasil karakerisasi dengan FTIR menunjukkan adanya gugus fungsi $C-H, C=O, C=N, C=C, C-N, C-O$, dan $C$ $C l$ pada daun sirih merah, hijau, dan hitam. Hasil analisis PCA memberikan nilai bilangan gelombang yang merupakan identitas daun sirih yaitu pada rentang $1670-1679 \mathrm{~cm}^{-1}$ dan diperkuat dengan hasil analisis K-Nearest Neightbourhood (KNN).
\end{abstract}

Kata kunci: Sirih, FTIR, Bilangan gelombang, PCA, KNN

\begin{abstract}
Research has been carried out on the identification of betel leaf (Piper sp.) wavenumbers using fourier transform infrared (FTIR) spectroscopy and Principal Component Analysis (PCA) methods. The kinds of betel leaf used are red betel (Piper Crocatum), green betel (Piper Betle L.), and black betel (Piper Betle V.). Tests were carried out on betel leaf powder with a betel mass ratio of 4:1 $\mathrm{KBr}, 0.011528 \mathrm{~g}$ and $0.002882 \mathrm{~g}$, respectively. The results of characterization by FTIR showed the presence of functional groups $C-H, C=O, C=N, C=C, C-N, C-O$, and $C-C l$ on red, green, and black betel leaves. The results of the PCA analysis provide the value of the wave number which is the identity of betel in the range 1670-1679 $\mathrm{cm}^{-1}$ and strengthened by the results of the K-Nearest Neighborhood (KNN) analysis.
\end{abstract}

Key words: Betel, FTIR, Wavenumber, PCA, KNN.

\section{Pendahuluan}

Tanaman sirih merupakan jenis tanaman dari suku Piperaceae, berkeping dua, berbunga, berpembuluh dan menghasilkan biji [1]. Tanaman sirih sering digunakan sebagai pengobatan herbal, dengan memanfaatkan bagian daun dari tanaman sirih. Daun sirih sudah digunakan dalam waktu yang lama karena memiliki beberapa khasiat untuk pengobatan. Karena khasiatnya ini, beberapa penelitian sudah dilakukan mengenai daun sirih. Seperti penelitian yang dilakukan oleh Kusuma (2017) mengenai karakterisasi ekstrak daun sirih merah (Piper Crocatum), dan didapatkan hasil bahwa daun sirih merah dapat digunakan sebagai pengobatan diabetes [2]. Pemanfaatan lain dari tanaman sirih juga dapat digunakan sebagai obat antibiotik. Lutviandhitarani (2015) sudah melakukan penelitian mengenai penggunaan daun sirih hijau (Piper Betle L.) sebagai pengganti antibiotik komersial untuk penanganan Mastitis. Mastitis merupakan peradangan yang terjadi di daerah sekitar kelenjar susu yang disebabkan oleh mikroorganisme seperti bakteri, zat kimia, dan luka karena mekanis [3]. Berdasarkan penelitian ini diketahui bahwa daun sirih hijau memiliki efektifitas dalam menghambat pertumbuhan bakteri. Maulida (2015) juga melakukan penelitian mengenai daun sirih yaitu, uji aktivitas antioksidan ekstrak daun sirih hitam (Piper Betle V.), dan didapatkan hasil bahwa ekstrak daun sirih hitam memiliki aktivitas sebagai 
antioksidan. Aktivitas antioksidan dari sirih hitam dapat digunakan sebagai pengobatan penyakit diabetes mellitus diakibatkan radikal bebas yang menyerang asam lemak tak jenuh dalam jaringan sel [4].

Berdasarkan beberapa penelitian yang sudah disebutkan, dapat diketahui bahwa daun sirih memiliki potensi yang besar sebagai pengobatan herbal. Produk sirih dalam bentuk serbuk sudah banyak beredar dipasaran sebagai bahan baku obat herbal. Untuk mengetahui kemurnian atau keaslian dari ekstrak sirih tersebut perlu dilakukan identifikasi. Dalam penelitian ini dilakukan identifikasi bilangan gelombang daun sirih, dimana identifikasi bilangan gelombang dilakukan pada serbuk daun sirih menggunakan metode spektroskopi FTIR. Nilai bilangan gelombang ini bersifat khas dan hanya dimiliki oleh daun sirih sehingga dapat dikatakan bahwa nilai tersebut merupakan identitas dari daun sirih.

\section{Landasan Teori}

\subsection{Tanaman sirih}

Tanaman sirih adalah tanaman yang memiliki bentuk berupa semak kayu di bagian pangkal, merambat atau memanjat, dengan tinggi tanaman dapat mencapai 5-15 $\mathrm{m}$. Terdapat beberapa jenis tanaman sirih, diantaranya tanaman sirih merah, sirih hijau, dan sirih hitam. Tanaman sirih merah berbentuk lonjong dan besar dengan ujung daun yang meruncing. Daun sirih merah berwarna hijau tua dengan corak garis dominan berwarna merah. Daun sirih merah cenderung lebih tebal dibandingkan dengan daun sirih hijau dan hitam. Daun tanaman sirih hijau memiliki ciri-ciri lebih kecil dan lebih tipis dibandingkan daun sirih merah. Warna daun sirih dominan hijau dengan permukaan daun yang beruas. Sedangkan daun pada tanaman sirih hitam memiliki ciri khusus yaitu bentuk daun menyerupai hati, bertangkai, daunnya berwarna hijau tua kehitaman dan bila dipegang daun terasa tebal dan kaku [5].

Daun sirih adalah bagian dari tanaman sirih yang sering digunakan sebagai pengobatan herbal. Daun sirih diketahui dapat mengatasi batuk, menghilangkan bau badan, mengobati luka bakar, menurunkan kolesterol, keputihan, dan gatal-gatal. Secara tradisional daun sirih digunakan sebagai obat antiradang, antiseptik, penghenti pendarahan, pereda batuk, perangsang keluarnya air liur, dan sebagai obat cacing [6].

\subsection{Spektroskopi Fourier Transform Infrared (FTIR)}

Spektroskopi FTIR adalah teknik pengukuran untuk mengumpulkan spektra inframerah. Energi yang diserap sampel pada berbagai frekuensi sinar inframerah yang direkam, kemudian diteruskan ke interferometer. Sinar pengukuran sampel diubah menjadi interferogram. Perhitungan selanjutnya dilakukan secara matematika sehingga menghasilkan spektra yang identik. Pada spektroskopi FTIR, jika suatu frekuensi tertentu dari radiasi inframerah dilewatkan pada sampel suatu senyawa organik maka akan terjadi penyerapan frekuensi oleh senyawa tersebut. Serapan yang terjadi pada spektroskopi FTIR menghasilkan spektra berupa grafik yang menunjukkan transmitansi yang bervariasi pada setiap frekuensi radiasi infra merah. Satuan frekuensi yang digunakan pada garis horizontal (absis) dinyatakan dalam bilangan gelombang, yang didefenisikan sebagai banyaknya gelombang dalam tiap satuan panjang [7].

\subsection{Principal Component Analysis (PCA)}

Principal Component Analysis adalah teknik yang digunakan untuk menyederhanakan suatu data, dengan cara mentransformasi data secara linier sehingga terbentuk sistem koordinat baru dengan varians maksimum. Analisis PCA dapat digunakan untuk mereduksi dimensi suatu data tanpa mengurangi karakteristik data tersebut secara signifikan. Analisis PCA bertujuan menerangkan struktur varianskovarians melalui kombinasi linear dari variabel-variabel. Analisis PCA ini sering kali dilakukan tidak saja merupakan akhir dari suatu pengolahan data tetapi juga merupakan tahap atau langkah dalam kebanyakan penelitian yang bersifat lebih besar dan luas [8].

Analisis PCA akan menampilkan kedudukan sampel daun sirih merah, hijau, dan hitam pada diagram kartesian. Proyeksi titik sampel pada analisis PCA akan dinyatakan dalam bentuk score plot. Selain itu, PCA dapat memberikan hasil loading plot yang akan menentukan rentangan bilangan gelombang yang menjadi ciri khas dari daun sirih.

\section{Metode Penelitian}

Alat dan bahan yang digunakan adalah spektroskopi FTIR Shimadzu IRPrestige-21, timbangan analitik, mortar, spatula kecil, blender, kertas aluminum, laptop, program The Unscrambler X10.4, Microsoft Excel 2016, masing-masing 30 lembar daun sirih jenis merah, hijau, hitam, dan KBr. Langkah pertama 
diawali dengan mengeringkan daun sirih merah, hijau, dan hitam pada suhu ruang $\left(25^{\circ} \mathrm{C}\right)$ selama 14 hari. Daun sirih kering selanjutnya dihaluskan menggunakan blender sampai diperoleh serbuk daun sirih. Serbuk daun sirih dan $\mathrm{KBr}$ masing-masing ditimbang dengan perbandingan massa 4:1, yaitu 0,011528 g dan $0,002882 \mathrm{~g}$ untuk pengujian dengan spektroskopi FTIR. Pengujian FTIR dilakukan dengan pengulangan sebanyak dua kali. Data spektra sirih disimpan untuk selanjutnya diolah di Micrososft Excel. Masing-masing data, yang meliputi nilai intensitas dan bilangan gelombang dari daun sirih merah, hijau, dan hitam dilakukan transpose data dan digabungkan dalam satu worksheet excel. Langkah berikutnya, data spektra gabungan dimasukkan pada program The Unscrambler dan dilakukan analisis PCA. Hasil (output) PCA berupa score plot dan loading plot.

\section{Hasil Dan Pembahasan}

\subsection{Spektra FTIR}

Dari hasil uji FTIR diperoleh spektra daun sirih merah, hijau, dan hitam seperti tampak pada Gambar 1. Tampak bahwa semua daun sirih memiliki pola spektrum FTIR yang sama dengan perbedaan pada nilai intensitas transmitansi dan pergeseran daerah bilangan gelombang dalam rentangan yang masih sama.

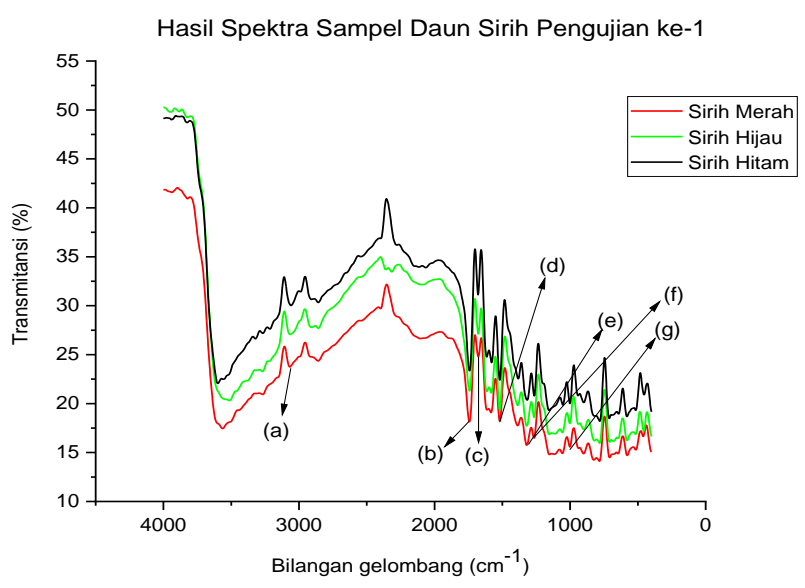

a)

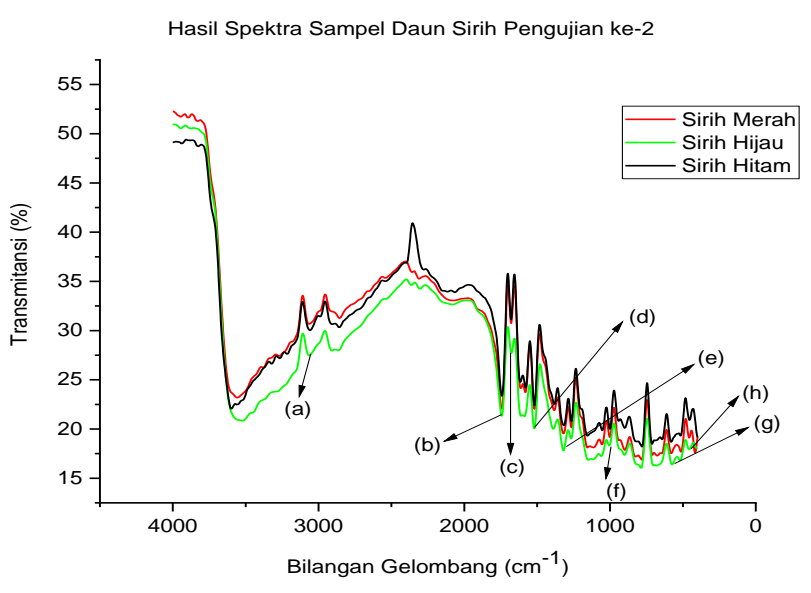

b)

Gambar 1. Spektra gabungan sampel daun sirih dengan dua kali pengulangan: (a) pengujian ke-1 (b) pengujian ke-2.

Pada Gambar 1a dan 1b tampak perbedaan pada puncak-puncak spektra yang mengalami pergeseran bilangan gelombang ke yang lebih kecil atau lebih besar. Seperti pada daun sirih merah, puncak a pada pengujian pertama menunjukkan daerah bilangan gelombang $3066,82 \mathrm{~cm}^{-1}$ bergeser ke arah bilangan gelombang yang lebih kecil yaitu di $3064,89 \mathrm{~cm}^{-1}$. Pergesaran juga terjadi pada puncak c untuk sirih hitam, dimana bilangan gelombang bergeser dari $1741,42 \mathrm{~cm}^{-1} \mathrm{ke} 1743,65 \mathrm{~cm}^{-1}$. Namun pergeseran bilangan gelombang ini masih berada pada rentang gugus fungsi yang sama dan masih dalam rentang sensitifitas alat yaitu $4 \mathrm{~cm}^{-1}$, sehingga perbedaan bilangan gelombang ini tidak menghasilkan interpretasi gugus fungsi yang berbeda pada pengujian pertama dan kedua. Berdasarkan hasil ini, diketahui bahwa spektra FTIR daun sirih merah, hijau, dan hitam menghasilkan pola spektra yang identik ditinjau dari posisi bilangan gelombang, intensitas, dan jumlah puncak [9]. Hal ini dapat disebabkan karena ketiga jenis daun sirih secara umum memiliki senyawa penyusun yang sama seperti alkaloid, polifenolat, flavonoid, dan beberapa unsur lainnya [10]. Berdasarkan spektra pada Gambar 1a dan 1b, diketahui bahwa sampel tersebut berasal dari spesies yang sama yaitu daun sirih dengan varietas yang berbeda (merah, hijau, dan hitam). Perbedaan varietas ini ditunjukan dari adanya perbedaan intensitas serapan pada tiap puncaknya dan adanya sedikit pergesaran bilangan gelombang, namun masih dalam rentang bilangan gelombang gugus fungsi tertentu.

Berdasarkan hasil spektra inframerah yang dihasilkan menunjukkan adanya serapan pada daerah sekitar bilangan gelombang $3066,82 \mathrm{~cm}^{-1}$ untuk daun sirih merah yang dapat diindikasikan sebagai vibrasi dari gugus fungsi $\mathrm{C}-\mathrm{H}$ aromatik dengan serapan yang tajam dan intensitas yang kuat. Pita serapan lainnya pada daun sirih merah juga muncul di daerah sekitar bilangan gelombang $1743,65 \mathrm{~cm}^{-1}$ dan $1676,14 \mathrm{~cm}^{-1}$ yang diidentifikasikan sebagai gugus fungsi $\mathrm{C}=\mathrm{O}$ aldehid, dan $\mathrm{C}=\mathrm{N}$ imin dengan intensitas 
keduanya yang kuat. Gugus fungsi $\mathrm{C}=\mathrm{C}$ aromatik muncul dengan intensitas sedang-lemah pada daerah vibrasi sekitar 1517,98 $\mathrm{cm}^{-1}$. Sedangkan untuk pita serapan $1321,24 \mathrm{~cm}^{-1}$ dan $1265,30 \mathrm{~cm}^{-1}$ adalah daerah vibrasi dari gugus fungsi $\mathrm{C}-\mathrm{N}$ dengan intensitas sedang-kuat [11]. Interpretasi gugus fungsi dari daun sirih merah, hijau, dan hitam selengkapnya ditampilkan pada Tabel 1.

Tabel 1. Interpretasi gugus fungsi daun sirih.

\begin{tabular}{ccccccc}
\hline Referensi & Puncak & Pengujian & \multicolumn{2}{c}{ Bilangan gelombang $\left(\mathrm{cm}^{-1}\right)$; Transmitansi $(\%)$} & \multirow{2}{*}{ Gugus fungsi } \\
\cline { 3 - 6 } & & ke- & Sirih Merah & Sirih Hijau & Sirih Hitam & \\
\hline $3150-3050$ & a & 1 & 3066,$82 ; 23,75$ & 3064,$89 ; 27,07$ & 3059,$10 ; 30,02$ & C-H (Alifatik) \\
& & 2 & 3064,$89 ; 30,67$ & 3064,$89 ; 27,48$ & 3064,$89 ; 30,69$ & \\
\hline $1740-1720$ & b & 1 & 1743,$65 ; 18,15$ & 1741,$72 ; 21,30$ & 1741,$72 ; 23,36$ & C=O (Aldehid) \\
& & 2 & 1743,$65 ; 22,06$ & 1743,$65 ; 21,32$ & 1741,$72 ; 26,63$ & \\
\hline $1650-1690$ & c & 1 & 1676,$14 ; 24,79$ & 1678,$07 ; 27,12$ & 1678,$07 ; 31,13$ & C=N (Imin) \\
& & 2 & 1678,$07 ; 30,75$ & 1676,$14 ; 27,72$ & 1678,$07 ; 32,59$ & \\
\hline $1600-1475$ & d & 1 & 1517,$98 ; 18,17$ & 1519,$91 ; 19,36$ & 1517,$98 ; 22,41$ & C=C (Aromatik) \\
& & 2 & 1517,$98 ; 22,02$ & 1519,$91 ; 20,03$ & 1519,$91 ; 23,06$ & \\
\hline $1350-1000$ & e & 1 & 1321,$24 ; 15,78$ & 1321,$24 ; 17,72$ & 1317,$38 ; 20,37$ & C-N (Amina) \\
& & 2 & 1319,$31 ; 19,54$ & 1319,$21 ; 17,82$ & 1321,$24 ; 20,33$ & \\
\hline $1350-1000$ & f & 1 & 1265,$30 ; 16,47$ & 1265,$3 ; 18,59$ & 1265,$30 ; 20,79$ & C-N (Amina) \\
& & 2 & 1265,$30 ; 20,14$ & 1267,$63 ; 19,03$ & 1267,$23 ; 21,43$ & \\
\hline $1300-1000$ & g & 1 & 1001,$06 ; 15,48$ & 1002,$98 ; 17,97$ & 1001,$06 ; 20,0$ & C-O (Eter) \\
& & 2 & 1001,$06 ; 19,17$ & 1002,$98 ; 18,34$ & 1002,$98 ; 20,47$ & \\
\hline$<667$ & h & 1 & 578,$64 ; 14,70$ & 580,$57 ; 16,23$ & 580,$57 ; 20,91$ & C-Cl (Klorin) \\
& & 2 & 580,$57 ; 17,53$ & 574,$79 ; 16,39$ & 578,$64 ; 18,79$ & \\
\hline
\end{tabular}

\footnotetext{
* dari ref [11].
}

Hasil pengujian sampel daun sirih menampilkan spektra yang membentuk puncak-puncak yang khas. Spektra infrared dengan rentang bilangan gelombang antara $1500-500 \mathrm{~cm}^{-1}$ bersifat identik untuk ketiga jenis daun sirih. Spektra dengan bilangan gelombang ini merupakan daerah sidik jari (fingerprint) yang bersifat khas dari senyawa pada sampel yang diuji. Berdasarkan interpretasi gugus fungsi yang dilakukan pada sampel daun sirih, diketahui pada daerah sidik jari (fingerprint) daun sirih memiliki gugus fungsi $\mathrm{C}=\mathrm{C}, \mathrm{C}-\mathrm{N}, \mathrm{C}-\mathrm{O}$, dan $\mathrm{C}-\mathrm{Cl}$. Untuk melihat lebih jelas daerah sidik jari ini, maka spektra pada Gambar 1 dipotong dalam range $1500-500 \mathrm{~cm}^{-1}$ dan spektranya terlihat pada Gambar 2.

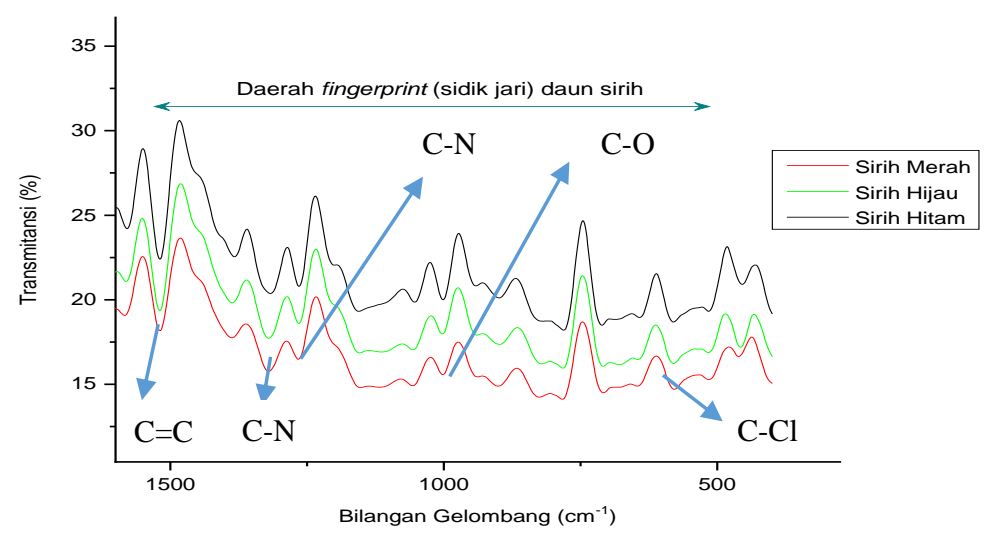

Gambar 2. Daerah fingerprint (sidik jari) sampel daun sirih.

Berdasarkan Gambar 2, ketiga jenis daun sirih memiliki gugus fungsi yang sama disetiap puncaknya. Perbedaan dari ketiganya terletak pada intensitas transmitansi. Intensitas transmitansi pada setiap sampel memiliki nilai yang bervariasi. Seperti pada daerah bilangan gelombang sekitar $1517 \mathrm{~cm}^{-1}$ daun sirih hitam memiliki puncak yang lebih tajam dengan intensitas transmitansi yang lebih tinggi yaitu $22,41 \%$. Daerah ini menunjukkan adanya gugus fungsi $\mathrm{C}=\mathrm{C}$ aromatik yang muncul dengan intensitas sedanglemah, sedangkan gugus fungsi C-N secara berturut-turut muncul pada daerah serapan 1321,24 dan 
$1265,30 \mathrm{~cm}^{-1}$ dengan intensitas keduanya adalah sedang-kuat [11]. Gugus fungsi C-N (amina) muncul pada daerah sidik jari (fingerprint) dapat diidentifikasikan sebagai gugus fungsi yang khas dari daun sirih. Gugus fungsi ini muncul dari senyawa alkaloid yang terkandung dalam daun sirih. Senyawa alkaloid berasal dari tumbuhan yang secara kimia merupakan bagian dari golongan basa organik amina. Gugus amina yang terdapat pada daerah sidik jari merupakan gugus amina siklik, yang ditandai dengan munculnya vibrasi tarik $\mathrm{N}$ tersier pada daerah sekitar bilangan gelombang $1320 \mathrm{~cm}^{-1}$ [12]. Sedangkan untuk gugus fungsi $\mathrm{C}-\mathrm{O}$ dan $\mathrm{C}-\mathrm{Cl}$ muncul pada daerah serapan 1001,06 dan 578,64 $\mathrm{cm}^{-1}$ dengan intensitas vibrasi yang lemah.

Apabila diamati spektra daun sirih pada Gambar 2, terlihat bahwa persen transmitansi sirih hitam menunjukkan nilai tertinggi diikuti dengan sirih hijau, dan sirih merah. Hal ini dapat ditandai dengan adanya gugus fungsi C-N (Amina) yang muncul berulang pada ketiga jenis daun sirih yang mempengaruhi nilai intensitas transmitansi tersebut [13].

\subsection{Analisis Data Daun Sirih dengan PCA}

\section{A. Score Plot}

Data spektra daun sirih jenis merah, hijau, dan hitam dengan dua kali pengulangan pada rentang bilangan gelombang 4000-500 $\mathrm{cm}^{-1}$ dimasukkan pada program The Unscrambler untuk dilakukan analisis. Hasil dari analisis PCA ini akan menunjukkan pengelompokkan sampel berdasarkan nilai PC-1 dan PC-2 berupa nilai score plot. Hasil dari analisis PCA ditunjukkan pada Gambar 3.

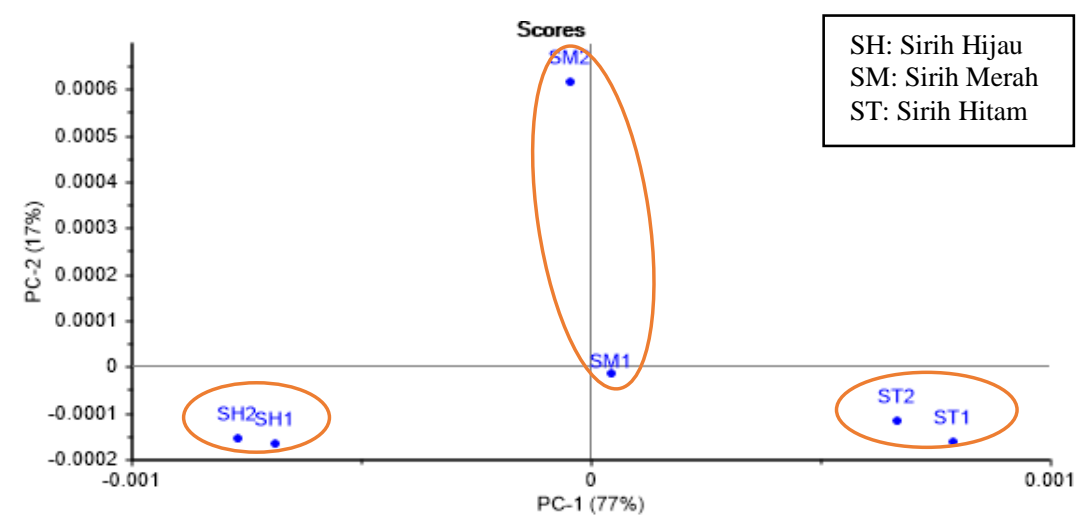

Gambar 3. Profil pengelompokkan sampel daun sirih dari hasil analisis PCA.

Pada Gambar 3, sampel daun sirih merah, hijau, dan hitam pada pengujian pertama dan kedua masing-masing dikelompokkan menjadi satu. Berdasarkan Gambar 3 pada PC-1 dapat menjelaskan 77\% dan PC-2 menjelaskan 17\% dari varian data. Total nilai PC dengan sampel daun sirih merah, hijau, dan hitam adalah 94\%. Nilai PC yang tinggi menunjukkan bahwa pemodelan score plot PCA berhasil menjelaskan 94\% bagian dari data spektra pengujian FTIR [14]. Proyeksi titik sampel daun sirih merah, hijau, dan hitam pada Gambar 3 lebih lengkap dapat dilihat pada Tabel 2.

Tabel 2. Nilai koordinat PC-1 dan PC-2 sampel daun sirih.

\begin{tabular}{lll}
\hline Sampel & PC-1 & PC-2 \\
\hline Sirih Merah Pengujian ke-1 & 0,0000 & 0,0000 \\
Sirih Merah Pengujian ke-2 & 0,0000 & 0,0006 \\
Sirih Hijau Pengujian ke-1 & $-0,0007$ & $-0,0002$ \\
Sirih Hijau Pengujian ke-2 & $-0,0008$ & $-0,0002$ \\
Sirih Hitam Pengujian ke-1 & 0,0008 & $-0,0002$ \\
Sirih Hitam Pengujian ke-2 & 0,0007 & $-0,0001$ \\
\hline
\end{tabular}

\section{B. Loading Plot}

Penentuan bilangan gelombang yang merupakan ciri khas dari daun sirih dapat dilakukan melalui analisis PCA dalam bentuk loading plot. Hasil PCA menampilkan hasil loading yang dapat memberikan informasi bilangan gelombang yang paling berkontribusi atau paling dominan dalam mendiskriminasikan sampel. Loading plot menunjukkan daerah rentangan bilangan gelombang yang diindikasikan sebagai ciri 
khas dari sampel daun sirih. Grafik loading hasil analisis PCA sampel daun sirih ditunjukkan pada Gambar 4.

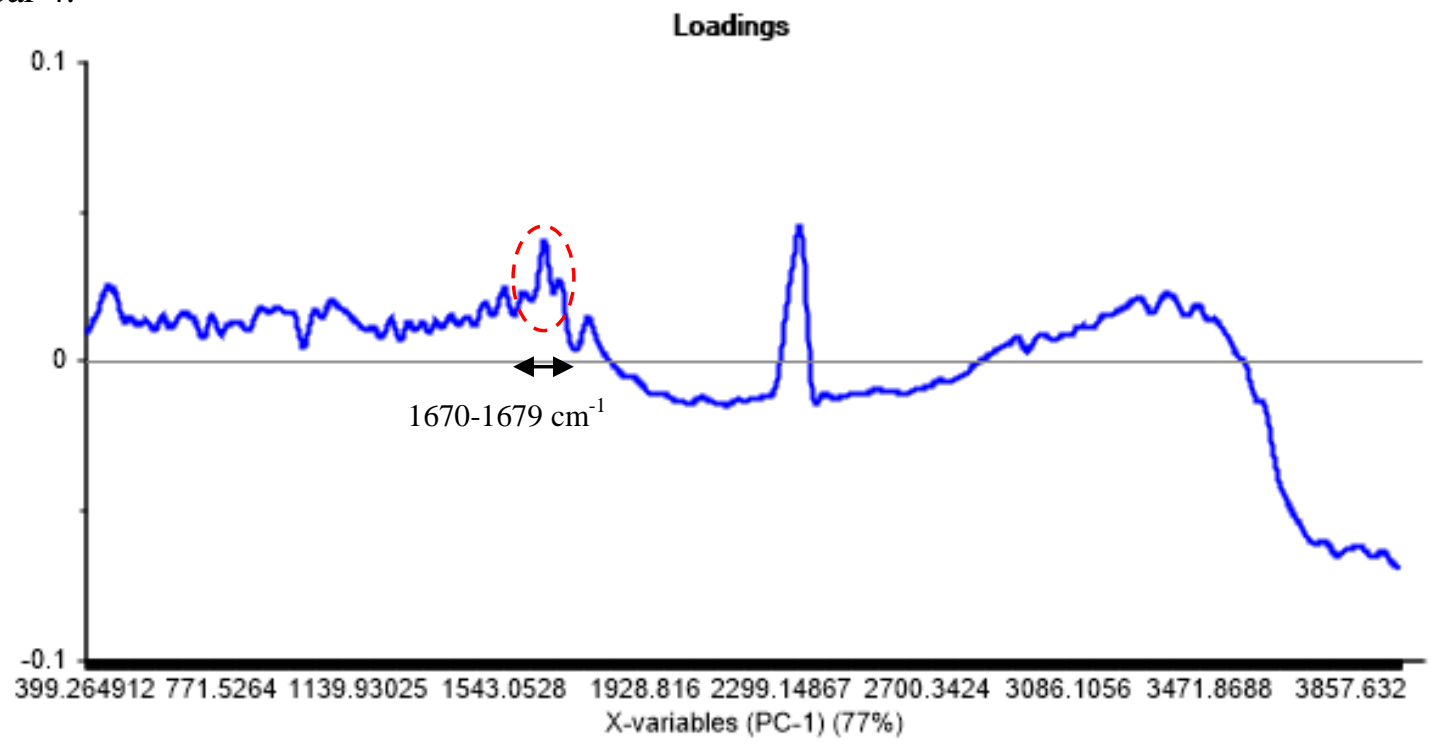

Gambar 4. Loading plot PCA daun sirih.

Berdasarkan Gambar 4 didapatkan identitas bilangan gelombang daun sirih berada pada rentang bilangan gelombang 1670-1679 $\mathrm{cm}^{-1}$. Puncak ini memberikan karakteristik yang khas pada spektra FTIR. Daerah 1670-1679 $\mathrm{cm}^{-1}$ merupakan rentang bilangan gelombang secara umum, yang dimiliki daun sirih jenis merah, hijau, dan hitam. Hal ini dibuktikan dari analisis KNN yang dilakukan untuk memverifikasi rentang bilangan gelombang tersebut. Hasil analisis KNN ditampilkan pada Tabel 3.

Tabel 3. Hasil KNN pada rentang bilangan gelombang $1670-1679 \mathrm{~cm}^{-1}$.

\begin{tabular}{|c|c|c|c|c|c|c|}
\hline Daun Sirih & $\begin{array}{l}\text { Bilangan gelombang } \\
\qquad\left(\mathrm{cm}^{-1}\right)\end{array}$ & Intensitas & Aktual & Hasil KNN & Ket. & $\begin{array}{l}\text { Persentase } \\
\text { Kebenaran }\end{array}$ \\
\hline \multirow[t]{6}{*}{ Sirih Merah } & 1670,35 & 25,15 & 1 & 1 & merah & \multirow{6}{*}{$100 \%$} \\
\hline & 1672,28 & 24,97 & 1 & 1 & merah & \\
\hline & 1674,21 & 24,85 & 1 & 1 & merah & \\
\hline & 1676,14 & 24,79 & 1 & 1 & merah & \\
\hline & 1678,07 & 24,79 & 1 & 1 & merah & \\
\hline & 1679,99 & 24,85 & 1 & 1 & merah & \\
\hline \multirow[t]{6}{*}{ Sirih Hijau } & 1670,35 & 27,7 & 0 & 0 & hijau & \multirow{6}{*}{$100 \%$} \\
\hline & 1672,28 & 27,43 & 0 & 0 & hijau & \\
\hline & 1674,21 & 27,24 & 0 & 0 & hijau & \\
\hline & 1676,14 & 27,13 & 0 & 0 & hijau & \\
\hline & 1678,07 & 27,12 & 0 & 0 & hijau & \\
\hline & 1679,99 & 27,2 & 0 & 0 & hijau & \\
\hline \multirow[t]{6}{*}{ Sirih Hitam } & 1670,35 & 32,6 & 1 & 1 & hitam & \multirow{6}{*}{$100 \%$} \\
\hline & 1672,28 & 32,05 & 1 & 1 & hitam & \\
\hline & 1674,21 & 31,6 & 1 & 1 & hitam & \\
\hline & 1676,14 & 31,28 & 1 & 1 & hitam & \\
\hline & 1678,07 & 31,13 & 1 & 1 & hitam & \\
\hline & 1679,99 & 31,14 & 1 & 1 & hitam & \\
\hline
\end{tabular}

Hasil KNN menunjukkan rentang bilangan gelombang 1670-1679 $\mathrm{cm}^{-1}$ memberikan persentase kebenaran $100 \%$ yang diartikan bahwa nilai ini benar dimiliki oleh daun sirih. Selain dari analisis KNN, munculnya puncak di daerah sekitar rentangan $1670-1679 \mathrm{~cm}^{-1}$ pada spektra FTIR juga memperkuat hasil loading plot. Spektra FTIR dari sirih merah, hijau, dan hitam menunjukkan karakteristik pada rentang tersebut seperti yang terlihat pada Tabel 1. 


\section{Kesimpulan}

Dari hasil penelitian dapat disimpulkan identitas bilangan gelombang daun sirih berada pada rentang $1670-1679 \mathrm{~cm}^{-1}$, yang diperkuat dari analisis KNN yang menunjukkan persentase kebenaran $100 \%$ pada rentang tersebut. Spektra FTIR dari daun sirih merah, hijau, dan hitam menunjukkan perbedaan pada intensitas transmitansi, dimana sirih hitam menunjukkan transmitansi paling tinggi, diikuti sirih hijau, dan sirih merah. Karakterisasi FTIR menunjukkan adanya gugus fungsi yang sama untuk ketiga jenis sirih yaitu, gugus $\mathrm{C}-\mathrm{H}, \mathrm{C}=\mathrm{O}, \mathrm{C}=\mathrm{N}, \mathrm{C}=\mathrm{C}, \mathrm{C}-\mathrm{N}, \mathrm{C}-\mathrm{O}$, dan $\mathrm{C}-\mathrm{Cl}$ pada semua jenis sirih merah, hijau, dan hitam.

\section{Ucapan Terima Kasih}

Terima kasih kepada Program Studi Fisika FMIPA, dan Laboratorium Bersama FMIPA Universitas Udayana atas dukungan dan fasilitas yang diberikan dalam pelaksanaan penelitian Tugas Akhir dan publikasi ilmiah ini.

\section{Pustaka}

[1] Iqbal, N. Rustam, dkk., Analisis Nilai Absorbansi Kadar Flavonoid Daun Sirih Merah (Piper crocatum) dan Daun Sirih Hijau (Piper betle L), Jurnal Gravitasi Vol. 15 No.1, Palu: Fakultas Matematika dan Ilmu Pengetahuan Alam Universitas Tadulako; 2014.

[2] E. W. Kusuma, D. Andriani, Karakterisasi Ekstrak Daun Sirih Merah (Piper Croctum, Ruiz\&Pav) sebagai Obat Antidiabetes Menuju Obat Herbal Terstandar, Jurnal Kesehatan Kusuma Husada, Sukoharjo: Program Studi Farmasi STIKES Nasional; 2017.

[3] G. Lutviandhitarani, Green Antibiotic Daun Sirih (Piper Betle L.), sebagai Pengganti Antibiotik Komersial untuk Penanganan Mastitis, Semarang: Fakultas Peternakan dan Pertanian Universitas Diponegoro; 2015.

[4] N. Maulida, Uji Aktivitas Antioksidan Ekstrak Daun Sirih Hitam (Piper Sp.) Terhadap DPPH (1,1Diphenyl-2-Picyryl Hydrazyl), Jurnal Sains dan Kesehatan, Samarinda: Fakultas Farmasi Universitas Mulawarman; 2015.

[5] Backer CA. and van den Brink RCB, Flora of Java (Spermatophytes only), Vol III, Wolters Noordhoff NV, Groningen, The Netherlands, 1968.

[6] M. N. Izrul, 14 Manfaat Daun Sirih untuk Kesehatan, Jakarta: Agro Media Pustaka, 2014. (Buku)

[7] Dachriyanus, Analisis Struktur Senyawa Organik secara Spektroskopi, Padang: Lembaga pengembangan teknologi informasi dan komunikasi (LPTIK) Universitas Andalas; 2004.

[8] J. N. Miller, J. C. Miller, Statistic and Chemometrics for Analytical Chemistry, Jilid 6, Ashfors Colour Press Ltd, Gosport UK, 2010, Hal: 221-248.

[9] Rohman, A. and Che Man, The Optimization of FTIR Spectroscopy Combined with Partial Least Square for Analysis of Animal Fats in Wuternary Mixtures, Spectroscopy: Biomedical Applications, 2011, 3-3:169-176.

[10] I. M. Scott, Jensen, H. R. Philogene, et al., A review of Piper sp. (Piperaceae) Phytochemistry, Insectidal Activity and Mode of Action, Phytochemistry Reviews. 2007, 7(1): 65.

[11] D. L. Pavia, Introduction to Spectroscopy Statitic, $4^{\text {th }}$ Edition, USA: Brooks Cole, 2008.

[12] S. Eko, Karaterisasi Senyawa Alkaloid Metabolit Sekunder dari Sponga Xestospongia Sp., Lampung: Fakultas Matematika dan Ilmu Pengetahuan Alam, Universitas Lampung; 2015.

[13] F. Azzahra, Isolasi dan Karakterisasi Alkaloid dari Daun Sirih Merah (Piper Crocatum Ruiz \& Pav), Bandung: Fakultas Matematika dan Ilmu Pengetahuan Alam Universitas Islam Bandung; 2015.

[14] D. Citrasari, Penentuan Adulterasi Daging Babi pada Nugget Ayam Menggunakan NIR dan Kemometrik [Skripsi]. Jember: Fakultas Farmasi Universitas Jember; 2015. 